\title{
Nodulation, arbuscular mycorrhizal colonization and growth of some legumes native from Brazil ${ }^{1}$
}

\author{
Camila M. Patreze ${ }^{2,3}$ and Lázara Cordeiro ${ }^{2}$
}

Received: August 29, 2003. Accepted: December 14, 2004

\begin{abstract}
RESUMO - (Nodulação, colonização micorrízica arbuscular e crescimento de algumas leguminosas nativas do Brasil). Foram examinados os efeitos da inoculação com rizóbio e micorriza, da fertilização com nitrogênio e fósforo na nodulação, na colonização micorrízica e no crescimento inicial das leguminosas arbóreas brasileiras Enterolobium contortisiliquum (Vell. Conc.) Morong, Inga laurina (Sw.) Willd., Lonchocarpus muehlbergianus Hassl e Platypodium elegans Vogel. O experimento foi conduzido em casa de vegetação usando sacos plásticos contendo uma mistura de solo arenoso de mata ciliar e vermiculita (2:1) fertilizados com nutriente basais incluindo NP, P e N inoculados ou não com rizóbio (r), micorriza (m) ou ambos (rm), totalizando sete tratamentos: NP, P, P+r, P+rm, N, N+m e N+rm, com dez repetições cada. As plantas foram analisadas aos 120 e 255 dias após o plantio. Tratamentos com deficiência de $\mathrm{P}$ afetaram negativamente o crescimento e nodulação de todas as espécies. Fungos micorrízicos arbusculares (FMAs) autóctones colonizaram as raízes do hospedeiro e as inoculações com fungos não aumentaram a colonização micorrízica, a qual foi favorecida pelo nível de $P$ adicionado. A nodulação foi relativamente alta em E. contortisiliquum e L. muehlbergianus, principalmente em tratamentos contendo $\mathrm{P}$, inoculados com rizóbio $(\mathrm{P}+\mathrm{r})$. Plantas deste tratamento desenvolveram-se melhor que as outras e, apesar dos rizóbios inoculados não apresentarem relações sinergísticas com os FMAs inoculados, também apresentaram as melhores porcentagens de colonização micorrízica. Além disso, estas duas espécies apresentaram maiores taxas de redução de acetileno e maior conteúdo de leghemoglobina. Estes resultados sugerem que E. contortisiliquum e L. muehlbergianus podem ter vantagens para se estabelecer em solos com baixos níveis de nitrogênio.
\end{abstract}

Palavras-chave: rizóbio, dupla inoculação, Enterolobium contortisiliquum, Inga laurina, Lonchocarpus muehlbergianus, Platypodium elegans

ABSTRACT - (Nodulation, arbuscular mycorrhizal colonization and growth of some legumes native from Brazil). The effects of rhizobial and mycorrhizal inoculation, nitrogen and phosphorus fertilization on nodulation, mycorrhizal colonization and initial growth were examined in Brazilian native plants, Enterolobium contortisiliquum (Vell. Conc.) Morong, Inga laurina (Sw.) Willd., Lonchocarpus muehlbergianus Hassl and Platypodium elegans Vogel. The experiment was carried out in a glasshouse using plastic bags filled with a mixture of sandy soil from riparian forest and vermiculite (2:1) amended with basal nutrients including NP, P and N and infected with rhizobia (r), mycorrhiza $(\mathrm{m})$ or both ( $\mathrm{rm}$ ), amounting seven treatments: NP, P, P+r, P+rm, N, N+m and N+rm, with ten replications each. The plants were analyzed at 120 and 255 days after sowing. P deficiency negatively affected growth and nodulation of all species. Autochton arbuscular mycorrhizal fungi (AMF) colonized host roots and fungal inoculations did not enhance mycorrhizal colonization, which was also favored by added P. Nodulation was relatively higher in E. contortisiliquum and L. muehlbergianus, mainly in treatments containing P, and with rhizobial inoculation $(\mathrm{P}+\mathrm{r})$. Plants from these treatments developed better than others and, despite the rhizobia inoculated had no synergistic relationship with inoculated AMF, they also showed the best percentages of mycorrhizal colonization. Moreover, these two species showed highest rates of acetylene reduction and highest leghemoglobin content. These results suggest that E. contortisiliquum and L. muehlbergianus can have advantages for establishment in soils with low nitrogen levels.

Key words : rhizobia, dual inoculation, Enterolobium contortisiliquum, Inga laurina, Lonchocarpus muehlbergianus, Platypodium elegans

\section{Introduction}

Dual inoculation with rhizobia and mycorrhizal fungi is currently being suggested as a possible solution to reforestation and amendment of soil fertility. The effectiveness of rhizobia-mycorrhiza-plant interactions varies with host species, rhizobial strain, fungus species and soil conditions. In contrast to taxonomically restricted $\mathrm{N}_{2}$-fixing rhizobia, arbuscular mycorrhizas are extremely widespread (Brundrett 2002), besides showing low specificity (Mosse 1975).

Relatively few leguminous trees have been tested for their nodulation or nitrogen fixation ability (Sprent 2001) and little is known about how we can manage

\footnotetext{
1 Part of the Master Thesis of the first Author

2 Universidade Estadual Paulista, Instituto de Biociências, Departamento de Botânica, C. Postal 199, CEP 13506-900, Rio Claro, SP, Brasil

3 Corresponding Author: cpatreze@cena.usp.br
} 
symbiotic fungal and rhizobial associations more effectively (Marques et al. 2001). Some woody legume species, for instance Albizia lebbeck (L.) Benth (Faria et al. 1995), Dalbergia nigra Allem. ex Benth (Santiago et al. 2002), Centrolobium tomentosum Guill. ex Benth (Marques et al. 2001) and Mimosa caesalpiniifolia Benth (Burity et al. 2000) have been studied in this way. Positive impacts of dual inoculation have been demonstrated in forest tree species in Philippines (De La Cruz et al. 1988), India (Khan \& Uniyal 1999) and Kenya (Munro et al. 1999).

Enterolobium contortisiliquum (Vell. Conc.) Morong plants have been used in enrichment planting and in agroforestry systems (Montagnini et al. 1997; Eibl et al. 2000). This species is tolerant to heavy metal contaminated soil (Trannin et al. 2001). It has been sampled in several Brazilian riparian forests (Catharino 1989; Nilsson 1989; Bernacci et al. 1998) and its nodulation has been known since 1906 (Allen \& Allen 1981). Arbuscular mycorrhizal fungi (AMF) colonization was reported by Frioni et al. (1999).

Inga laurina (Sw.) Willd. is generally found in riparian forests primarily in seasonally flooded areas (Romagnolo \& Souza 2000), but it has also long been used as a shade tree and green manure in coffee and cacao plantations and has good potential as an agroforestry species (Tilki \& Fisher 1998). It was listed as a nitrogen-fixing tree by Halliday \& Nakao (1982) and under its currently accepted synonym I. fagifolia, (L.) Benth. was reported to be nodulated (Faria et al. 1987). However these studies did not include any information on nodule physiology. AMF colonization in I. laurina has not been reported previously, although other Inga species are known to form such symbioses.

Lonchocarpus muehlbergianus Hassl has been used in carpentry and as an ornamental species (Lorenzi 1992). The genus includes 130 species of shrubs or trees from tropical and subtropical America and one species in Africa. L. muehlbergianus is one of 21 species from this genus with known nodulation capacity (Sprent 2001). Faria et al. (1987) were the first to observe its nodulation. This species can be founded in riparian forest (Silva et al. 1992; Bernacci et al. 1998; Nilsson 1989). Frioni et al. (1999) observed colonization by AMF in L. nitidus.

Platypodium elegans Vogel is used for wood and as an ornamental, mainly along the streets and avenues (Lorenzi 1994). This species was reported as nodulated by Halliday \& Nakao (1982). It was sampled in $23.9 \%$ of studies involving floristic survey of riparian forest of Brazil (Rodrigues \& Nave 2000). Carneiro et al.
(1998) characterized the occurrence of AMF of $P$. elegans in a nursery.

The aim of this work was to investigate the effects of inoculation with rhizobia and/or arbuscular mycorrhizal fungi on nodulation, mycorrhizal colonization and growth of E. contortisiliquum, I. laurina, L. muehlbergianus and P. elegans under greenhouse conditions and different fertilization treatments.

\section{Materials and methods}

Seeds of all species were surface sterilized. E. contortisiliquum and P. elegans seeds were scarified to break dormancy prior to planting. E. contortisiliquum seeds were smoothed and P. elegans seeds were left to soak in $50 \%$ sulphuric acid during $45 \mathrm{~min}$ and washed nine times prior to planting. I. laurina seeds were firstly surface sterilized and stored in trays with vermiculite and abscisic acid solution $\left(10^{-4} \mathrm{M}\right)$ in the proportion $2: 1 \mathrm{v} / \mathrm{v}$ in a cold chamber at $10 \pm 1{ }^{\circ} \mathrm{C}$ and $85 \% \pm 5 \%$ of relative humidity (Barbedo \& Cicero 2000) during twenty-four days, since seeds of Inga species rapidly lose viability under normal environmental conditions. After that, the seeds of these species and L. muehlbergianus were germinated directly on substrate.

Aerial parts of collected species were pressed and catalogued at Bioscience Institute Herbarium - UNESP (Universidade Estadual Paulista "Júlio de Mesquita Filho") under the numbers HRCB-34503 (E. contortisiliquum), HRCB- 5021 (I. laurina), HRCB-34500 (L. muehlbergianus) and HRCB-34502 (P. elegans).

Seeds of all species, except I. laurina, were soaked in a turbid suspension $(100 \mathrm{~mL})$ of a mixture of two rhizobia strains for one hour before sowing. E. contortisiliquum seeds were inoculated with a mixture of strains IBRC-206 and 207, isolated from E. contortisiliquum nodules. L. muehlbergianus and P. elegans seeds were inoculated with IBRC-208 and 209 rhizobia strains isolated from nodules of L. muehlbergianus. Pre-germinated seedlings of I. laurina received $10 \mathrm{~mL}$ of a mixture of IBRC- 195 and 197 strains isolated from Inga spp., directly on surface of pots, one week after sowing. To ensure rhizobia infection, seedlings of all species were reinoculated 30 days after sowing, with $10 \mathrm{~mL}$ of rhizobia suspension containing the same strains.

For mycorrhizal inoculation, pieces of Anadenathera peregrina (L.) Speg. var. falcata (Benth.) Altschul roots 
$\pm 1 \mathrm{~cm}$ in length, collected from Corumbataí Cerrado ( $22^{\circ} 15^{\prime} \mathrm{S}$ and $47^{\circ} 00^{\prime} \mathrm{W}, 810 \mathrm{~m}$ a.s.1.) were added on each pot surface $(0.4 \mathrm{~g})$ near seedlings stem twenty-eight days after sowing as described by Gross et al. (2004). The roots of A. peregrina var. falcata (used as inoculum) had been previously characterized by Gross et al. (2004) that identified spores of Glomus microaggregatum Koske, Glomus etunicatum Becker \& Gerd., Glomus sp., Enthrophospora sp., Gigaspora sp. and Acaulospora. Our preliminary tests showing hyphae and spores of mycorrhiza inside pieces of $A$. peregrina var. falcata roots proved its potential as inocule.

Aerial parts of this species were catalogued in the Bioscience Institute Herbarium - UNESP under the number HRCB-34330.

Plants were grown in plastic pots of $4 \mathrm{~L}$ containing non-sterile soil and vermiculite $(2: 1)$, in a greenhouse, under natural daylight, in seven randomized blocks. The soil was collected from riparian forest of Corumbataí, SP, Brazil (22'20'S and 47 40'W, $604 \mathrm{~m}$ a.s.1.) and contained in $\mathrm{mmol}_{\mathrm{c}} \cdot \mathrm{dm}^{-3}$ : $\mathrm{K}(1), \mathrm{Ca}(12), \mathrm{Mg}(4), \mathrm{H}+\mathrm{Al}$ (10), Al (7); in mg.dm ${ }^{-3}$ : B (0.01), Cu (0.07), Fe (23), Mn (8.7), Zn (0.4), S (9), P (7) and in ppm: N (1000) with $\mathrm{pH}$ 5.5. All pots received the following basal nutrients prior to sowing (in $\mathrm{mg}$. $\mathrm{kg}^{-1}$ substrate): $\mathrm{K}(60)$, $\mathrm{CaCO}_{3}(80), \mathrm{MgCO}_{3}(40), \mathrm{S}$ (30), B (1), Zn (2), Cu (2), Fe (4), Mn (20) Mo (4). Nitrogen and phosphorus were added at three different levels: NP, with $\mathrm{N}(40)$ and $\mathrm{P}_{2} \mathrm{O}_{5}(80)$; $\mathrm{P}$, with $\mathrm{P}_{2} \mathrm{O}_{5}(80)$ and $3.8 \mathrm{mM}$ of $\mathrm{N}$ as a start dose; and $\mathrm{N}$, with $\mathrm{N}(40)$, using $\mathrm{NH}_{4} \mathrm{NO}_{3}$. These lots varied in function of inoculations with rhizobia (r), mycorrhiza $(\mathrm{m})$ or both (rm). So, our experiment had seven treatments, with ten replicates each: NP; P; P+r; $\mathrm{P}+\mathrm{rm} ; \mathrm{N} ; \mathrm{N}+\mathrm{m} ; \mathrm{N}+\mathrm{rm}$. Additional nutrients $(10 \mathrm{~mL}$ of solution) were added to the surface of each pot every 30 days, according to fertilization treatments above.

The plant height was measured at two weeks intervals from 30 days after sowing until the end of the experiment (255 days after sowing). Five plants per treatment were harvested 120 days after sowing and fresh nodules were sieved and counted those larger than $4 \mathrm{~mm}$, between $2-4 \mathrm{~mm}$ and less than $2 \mathrm{~mm}$ of diameter. The other five plants per treatment were harvested 255 days after sowing, for leaf area measurement (CI-202 Area Meter, CID, Inc), dry weight of roots, stems and leaves, AMF colonization and nitrogen and phosphorus content of shoot tissues and substrate.

Nitrogenase activity and leghemoglobin content were evaluated in the nodules of two plants per treatment. Nitrogenase activity was measured by the acetylene reduction activity (ARA; Hardy et al. 1968) using the whole root system, and leghemoglobin content by the method of Becana et al. (1986) at $540 \mathrm{~nm}$, using three samples of $0.5 \mathrm{~g}$ each. After that, fresh nodules were sieved to separate those larger than $4 \mathrm{~mm}$, between 2 and $4 \mathrm{~mm}$ and less than $2 \mathrm{~mm}$ of diameter. They were then counted and dried. Nodule morphology was classified according to Sprent (2001).

Roots were stained (Philips \& Hayman 1970) and percentage of AMF infected roots of two plants per treatment was estimated using the gridline intersects method (Giovannetti \& Mosse 1980) under a stereomicroscope $(40 \mathrm{x})$ at 255 days after sowing.

Data were analyzed separately by ANOVA and means were compared by Duncan's test, at $P \leq 0.05$, using the Statistica for Windows (StatSoft, Inc. 2000), except for $\mathrm{P}$ and $\mathrm{N}$ contents that were analyzed on combined samples (per treatment), AMF colonization, ARA and leghemoglobin content that were evaluated in two plants per treatment.

\section{Results}

Plants that received NP were the tallest $(P<0.05)$ in relation to other treatments, mainly $\mathrm{N}$ treatments (phosphorous deficiency) (Fig. 1). E. contortisiliquum plants cultured on $\mathrm{P}$ and $\mathrm{P}+\mathrm{r}$ treatments were as tall as the NP plants at 255 days (Fig. 1). Plants of this species receiving $\mathrm{P}+\mathrm{r}$ treatment had highest leaf area. The dry mass of leaf, stem and root were also high, but did not differ of NP ones (Tab. 1). For I. laurina, $\mathrm{N}, \mathrm{N}+\mathrm{m}$ and $\mathrm{N}+\mathrm{rm}$ treated plants had leaf area similar to NP. For P. elegans, NP treatment differed significantly from the others in all growth parameters. P-fertilized treatments showed the best results of plant growth at 255 days in E. contortisiliquum and L. muehlbergianus (Fig. 1). Rhizobia inoculation in P-fertilized plants increased leaf area, leaf, stem and root dry mass of L. muehlbergianus at 255 days after sowing (Tab. 1).

Mycorrhizal colonization was relatively low in all species (Tab. 1). Percentage of AMF colonization of roots reached $24.72 ; 45.25 ; 39.48$ and $15.35 \%$ in $E$. contortisiliquum, I. laurina, L. muehlbergianus and P. elegans, respectively (Tab. 1). However, the highest values of AMF colonization occurred in $\mathrm{P}$ treatments inoculated with rhizobia, therefore non-inoculated with AMF in E. contortisiliquum and L. muehlbergianus. This indicates higher potential of infection by native fungi in the soil used as substrate and it becomes evident that the $\mathrm{P}$ fertilization is important for the 
530 Patreze \& Cordeiro: Nodulation, arbuscular mycorrhizal colonization and growth of some legumes native from Brazil

establishment of AMF. For I. laurina, AMF colonization occurred with both the inoculated and native fungi and it is the first register of AMF colonization in this species.

All nodulated species and nodules were identified as indeterminate (Corby 1988; Sprent 2001). We consider E. contortisiliquum and L. muehlbergianus as astragaloids (or caesalpinoids), I. laurina and $P$. elegans as mucunoid and aeschynomenoid respectively. All species, except $P$. elegans, were well nodulated and the nodules had a reddish internal colour (Fig. 2 D-F). Most part of nodules was between two
E. contortisiliquum
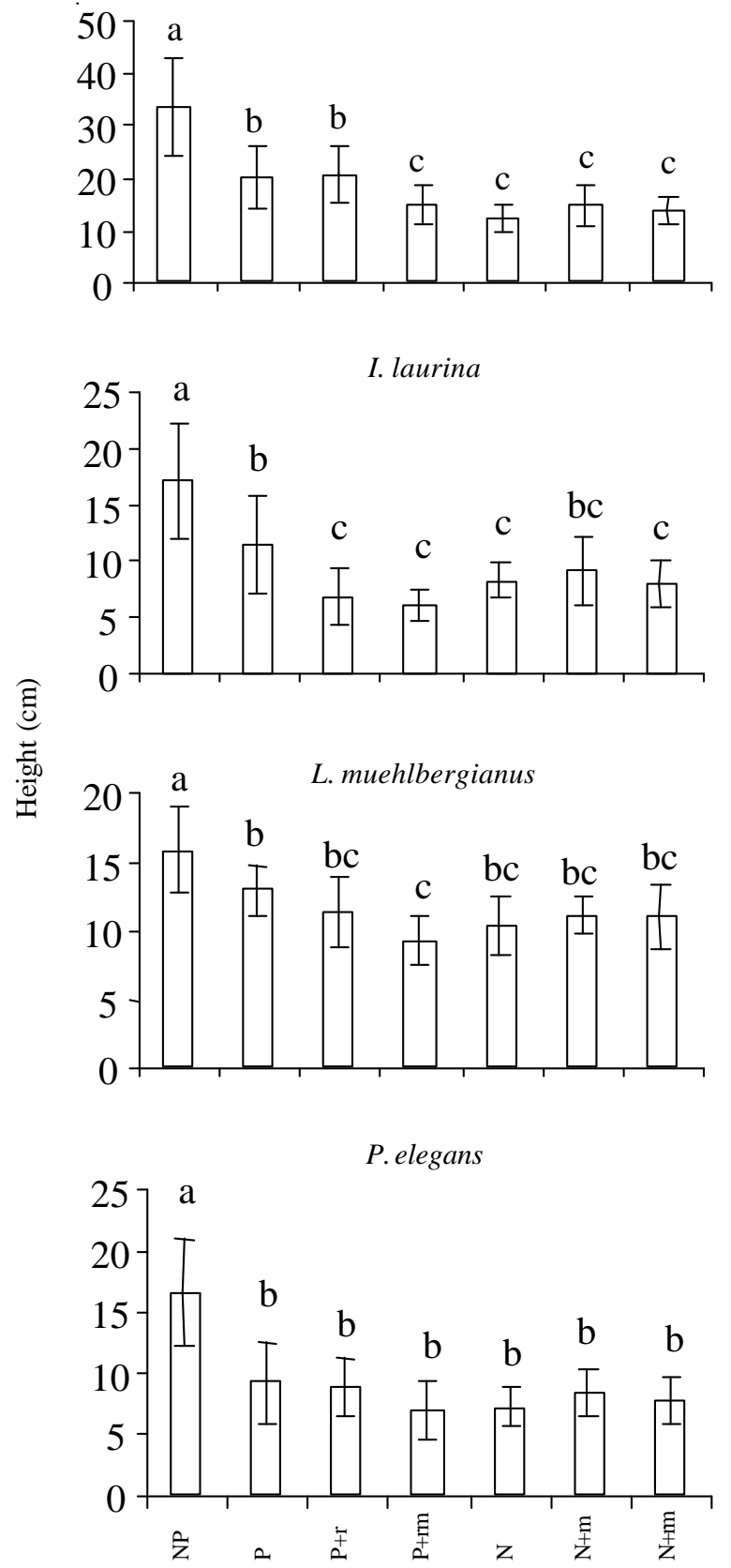

\section{E. contortisiliquum}

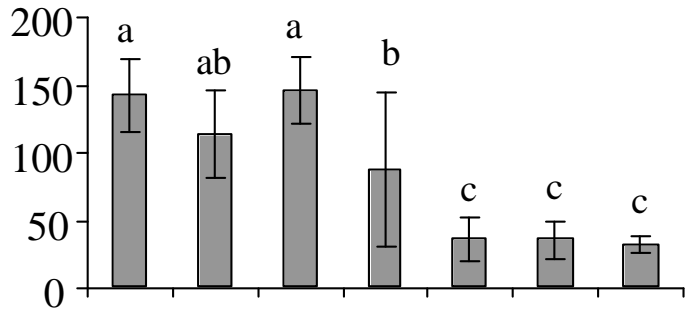

I. laurina
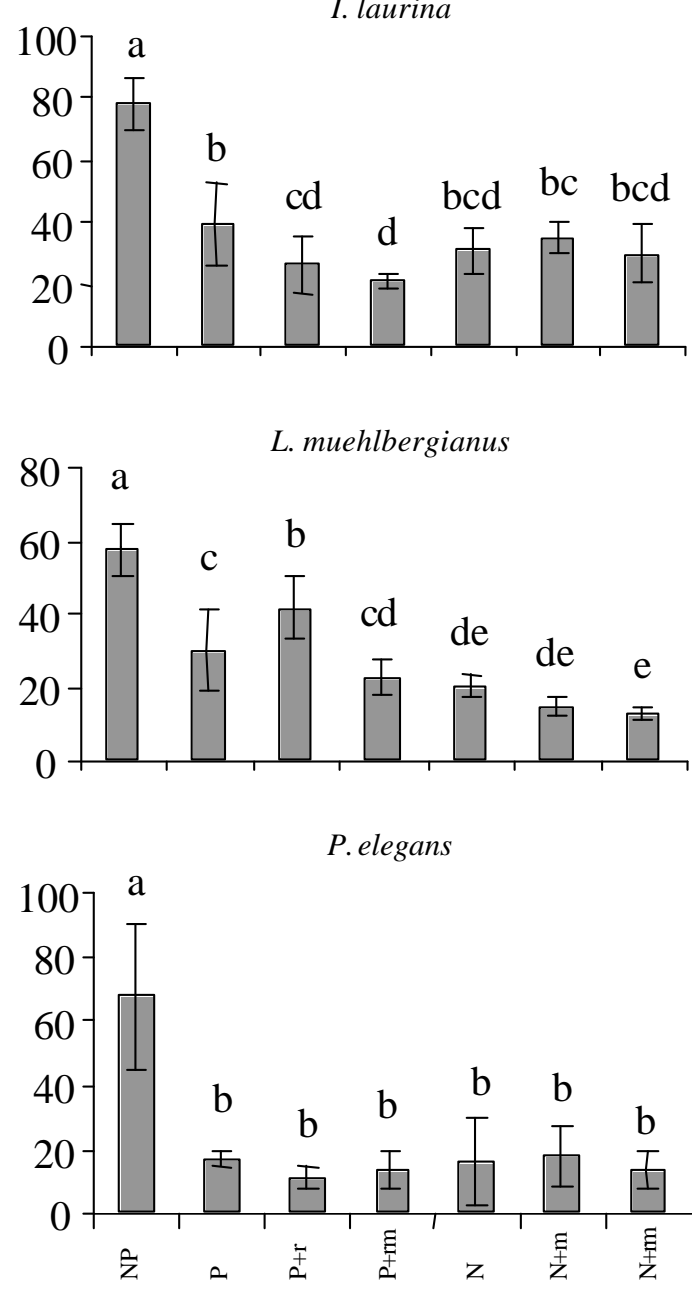

Treatments

Figure 1. Average height of Enterolobium contortisiliquum (Vell. Conc.) Morong, Inga laurina (Sw.) Willd., Lonchocarpus muehlbergianus Hassl and Platypodium elegans Vogel. seedlings at 120 and 255 days after sowing and growth under greenhouse conditions, fertilized with $\mathrm{NP}, \mathrm{P}, \mathrm{N}$ and inoculated by rhizobia $(\mathrm{r})$, mycorrhiza $(\mathrm{m})$ or both $(\mathrm{rm})$. Values followed by the same letter(s) are not significantly different at $5 \%$ level using the Duncan test. $\square=120$ days; $\square=255$ days. 
Table 1. Response of Enterolobium contortisiliquum (Vell. Conc.) Morong, Inga laurina (Sw.) Willd, Lonchocarpus muehlbergianus Hassl and Platypodium elegans Vogel seedlings to treatments of mineral fertilization (NP, $\mathrm{P}, \mathrm{N}$, ) and inoculation with rhizobia (r), mycorrhiza (m) or both (rm) at 255 days.

\begin{tabular}{|c|c|c|c|c|c|c|c|c|c|c|c|c|}
\hline \multirow[t]{2}{*}{ Treatment } & \multirow{2}{*}{$\begin{array}{l}\text { Leaf area } \\
\left(\mathrm{cm}^{2}\right)^{-1}\end{array}$} & \multicolumn{6}{|c|}{ Dry mass $(\mathrm{g})^{*}$} & \multirow{2}{*}{$\begin{array}{l}\text { AMF } \\
(\%)\end{array}$} & \multicolumn{2}{|c|}{$\mathrm{N}(\%)$} & \multicolumn{2}{|c|}{$\mathrm{P}(\%)$} \\
\hline & & Leaf & & SteM & & Root & & & Tissue & Substrate & Tissue & Substrate \\
\hline \multicolumn{13}{|c|}{ E. contortisiliquum } \\
\hline NP & $338.6 \mathrm{~b}$ & 13.78 & $a b$ & 33.68 & & 16.09 & a & 11.78 & 2.45 & 0.05 & 0.20 & 0.0078 \\
\hline $\mathrm{P}$ & $727.1 \mathrm{ab}$ & 9.41 & $\mathrm{~b}$ & 15.71 & & 12.01 & $\mathrm{~b}$ & 2.94 & 2.50 & 0.05 & 0.20 & 0.0126 \\
\hline $\mathrm{P}+\mathrm{r}$ & $1397.2 \mathrm{a}$ & 20.15 & a & 34.47 & $\mathrm{a}$ & 24.43 & $\mathrm{a}$ & 24.72 & 2.05 & 0.05 & 0.13 & 0.0142 \\
\hline $\mathrm{P}+\mathrm{rm}$ & $1121.7 \mathrm{a}$ & 12.44 & $\mathrm{~b}$ & 18.14 & $\mathrm{~b}$ & 16.03 & $a b$ & 18.27 & 2.00 & 0.07 & 0.18 & 0.0085 \\
\hline $\mathrm{N}$ & $204.0 \mathrm{~b}$ & 1.96 & $\mathrm{c}$ & 3.03 & & 3.81 & $\mathrm{~b}$ & 9.04 & 3.30 & 0.05 & 0.06 & 0.0008 \\
\hline $\mathrm{N}+\mathrm{m}$ & $266.3 \mathrm{~b}$ & 1.97 & $\mathrm{c}$ & 2.53 & $\mathrm{c}$ & 5.01 & $\mathrm{~b}$ & 10.59 & 3.55 & 0.07 & 0.06 & 0.0004 \\
\hline $\mathrm{N}+\mathrm{rm}$ & $116.4 \mathrm{~b}$ & 1.48 & $\mathrm{c}$ & 1.91 & & 2.71 & $\mathrm{~b}$ & 11.03 & 3.90 & 0.05 & 0.06 & 0.0003 \\
\hline \multicolumn{13}{|l|}{ I. laurina } \\
\hline NP & $503.4 \mathrm{a}$ & 15.30 & $\mathrm{a}$ & 9.81 & & 15.63 & $\mathrm{a}$ & 13.41 & 1.90 & 0.05 & 0.20 & 0.0074 \\
\hline $\mathrm{P}$ & $132.6 \mathrm{~b}$ & 5.10 & $\mathrm{~b}$ & 2.16 & $\mathrm{~b}$ & 4.19 & $\mathrm{~b}$ & 37.04 & 1.90 & 0.05 & 0.28 & 0.0096 \\
\hline $\mathrm{P}+\mathrm{r}$ & $139.9 \mathrm{~b}$ & 2.31 & $\mathrm{c}$ & 0.85 & $\mathrm{~cd}$ & 1.57 & $\mathrm{bc}$ & 4.85 & 1.80 & 0.05 & 0.31 & 0.0155 \\
\hline $\mathrm{P}+\mathrm{rm}$ & $182.9 \mathrm{~b}$ & 2.01 & $\mathrm{c}$ & 0.64 & $\mathrm{~d}$ & 0.87 & $\mathrm{c}$ & 45.25 & 1.85 & 0.05 & 0.46 & 0.0124 \\
\hline $\mathrm{N}$ & $379.4 \mathrm{ab}$ & 4.18 & $\mathrm{~b}$ & 1.46 & bcd & 4.05 & $\mathrm{bc}$ & 23.68 & 1.00 & 0.07 & 0.08 & 0.0009 \\
\hline $\mathrm{N}+\mathrm{m}$ & $377.3 \mathrm{ab}$ & 4.84 & $\mathrm{~b}$ & 1.85 & $\mathrm{bc}$ & 3.91 & $\mathrm{bc}$ & 6.26 & 2.00 & 0.07 & 0.07 & 0.0002 \\
\hline $\mathrm{N}+\mathrm{rm}$ & $280.6 \mathrm{ab}$ & 4.10 & $\mathrm{~b}$ & 1.97 & $\mathrm{~b}$ & 3.63 & $\mathrm{bc}$ & 16.78 & 1.65 & 0.05 & 0.06 & 0.0001 \\
\hline \multicolumn{13}{|c|}{ L. muehlberianus } \\
\hline NP & $1063.7 \mathrm{ab}$ & 8.79 & $\mathrm{~b}$ & 10.09 & & 19.34 & $a b$ & 1496 & 2.50 & 0.04 & 0.24 & 0.0064 \\
\hline $\mathrm{P}$ & $646.0 \mathrm{bc}$ & 5.70 & $\mathrm{bc}$ & 4.66 & $\mathrm{~b}$ & 16.03 & $a b$ & 39.48 & 2.60 & 0.05 & 1.17 & 0.0079 \\
\hline $\mathrm{P}+\mathrm{r}$ & $1257.1 \mathrm{a}$ & 11.30 & $\mathrm{a}$ & 8.55 & $\mathrm{a}$ & 22.07 & $\mathrm{a}$ & 12.37 & 2.75 & 0.05 & 1.21 & 0.0111 \\
\hline $\mathrm{P}+\mathrm{rm}$ & $489.4 \mathrm{~cd}$ & 3.88 & $\mathrm{~cd}$ & 2.71 & $\mathrm{bc}$ & 11.97 & $a b c$ & 9.21 & 3.35 & 0.06 & 0.20 & 0.0134 \\
\hline $\mathrm{N}$ & $132.9 \mathrm{~d}$ & 1.67 & $\mathrm{~d}$ & 1.48 & $\mathrm{c}$ & 4.31 & $\mathrm{bc}$ & 5.68 & 3.05 & 0.05 & 0.09 & 0.0018 \\
\hline $\mathrm{N}+\mathrm{m}$ & $42.8 \mathrm{~d}$ & 0.93 & d & 0.71 & & 7.78 & $\mathrm{bc}$ & 16.55 & 4.25 & 0.05 & 0.08 & 0.0003 \\
\hline $\mathrm{N}+\mathrm{rm}$ & $50.6 \mathrm{~d}$ & 0.77 & d & 0.54 & $\mathrm{c}$ & 2.16 & $\mathrm{c}$ & 12.34 & 4.55 & 0.06 & 0.06 & 0.0001 \\
\hline \multicolumn{13}{|l|}{ P.elegans } \\
\hline NP & $257.4 \mathrm{a}$ & 2.86 & a & 3.37 & & 4.99 & $\mathrm{a}$ & 9.03 & 3.00 & 0.05 & 0.35 & 0.0104 \\
\hline $\mathrm{P}$ & $27.1 \mathrm{~b}$ & 0.43 & $\mathrm{~b}$ & 0.25 & & 1.91 & $\mathrm{~b}$ & 15.35 & 2.45 & 0.05 & 0.68 & 0.0086 \\
\hline $\mathrm{P}+\mathrm{r}$ & $7.7 \mathrm{~b}$ & 0.23 & $\mathrm{~b}$ & 0.16 & $\mathrm{~b}$ & 0.95 & $\mathrm{~b}$ & 0 & 2.15 & 0.05 & 0.46 & 0.0063 \\
\hline $\mathrm{P}+\mathrm{rm}$ & $10.4 \mathrm{~b}$ & 0.27 & $\mathrm{~b}$ & 0.24 & $\mathrm{~b}$ & 0.62 & $\mathrm{~b}$ & 0 & 2.10 & 0.05 & 0.07 & 0.0056 \\
\hline $\mathrm{N}$ & $4.5 \mathrm{~b}$ & 0.31 & $\mathrm{~b}$ & 0.31 & $\mathrm{~b}$ & 0.93 & $\mathrm{~b}$ & 12.42 & 2.60 & 0.05 & 0.76 & 0.0006 \\
\hline $\mathrm{N}+\mathrm{m}$ & $7.4 \mathrm{~b}$ & 0.37 & $\mathrm{~b}$ & 0.37 & & 0.93 & $\mathrm{~b}$ & 1.81 & 2.85 & 0.06 & 0.11 & 0.0004 \\
\hline $\mathrm{N}+\mathrm{rm}$ & $4.5 \mathrm{~b}$ & 0.14 & $\mathrm{~b}$ & 0.14 & & 0.49 & $\mathrm{~b}$ & 3.46 & 3.25 & 0.07 & 0.11 & 0.0003 \\
\hline
\end{tabular}

*Values followed by the same letter(s) in the columns are not statistically different at $5 \%$ level determined by Duncan test.

and four $\mathrm{mm}$ in diameter (Fig. 2 and 3). Nodulation was suppressed by $\mathrm{N}$-fertilizer and/or P deficiency $(\mathrm{N}$, $\mathrm{N}+\mathrm{m}$ and $\mathrm{N}+\mathrm{rm}$ ). The highest numbers and dry weight of nodules were observed in E. contortisiliquum, I. laurina and L. muehlbergianus plants grown in $\mathrm{P}$, $\mathrm{P}+\mathrm{r}$ and $\mathrm{P}+\mathrm{rm}$ treatments (Fig. 3 and Tab. 2), showing the success of rhizobia inoculation in these plants.

Nitrogenase activity (ARA) and leghemoglobin content were higher in E. contortisiliquum and L. muehlbergianus than I. laurina and P. elegans (Tab. 2). Due to the low numbers and small size of nodules from $P$. elegans, we were unable to obtain accurate data on nodule mass, nitrogenase activity and leghemoglobin content.

\section{Discussion}

Phosphorus nutrition appeared to be the major factor influencing growth and nodulation of these species. Low phosphorus availability is the limiting factor for plant growth in more than $60 \%$ of tropical soils and this affects particularly symbiotic legumes, which usually have higher $P$ requirements than nonsymbiotic plants (Vadez et al. 1997), partly associated with their $\mathrm{N}_{2}$ fixing capability (Frioni et al. 1999). Similar P effects have been reported in Leucaena leucocephala (Lam.) de Wit. by Brandon et al. (1997). In our experiments, E. contortisiliquum and L. muehlbergianus grew well in the presence of 
532 Patreze \& Cordeiro: Nodulation, arbuscular mycorrhizal colonization and growth of some legumes native from Brazil
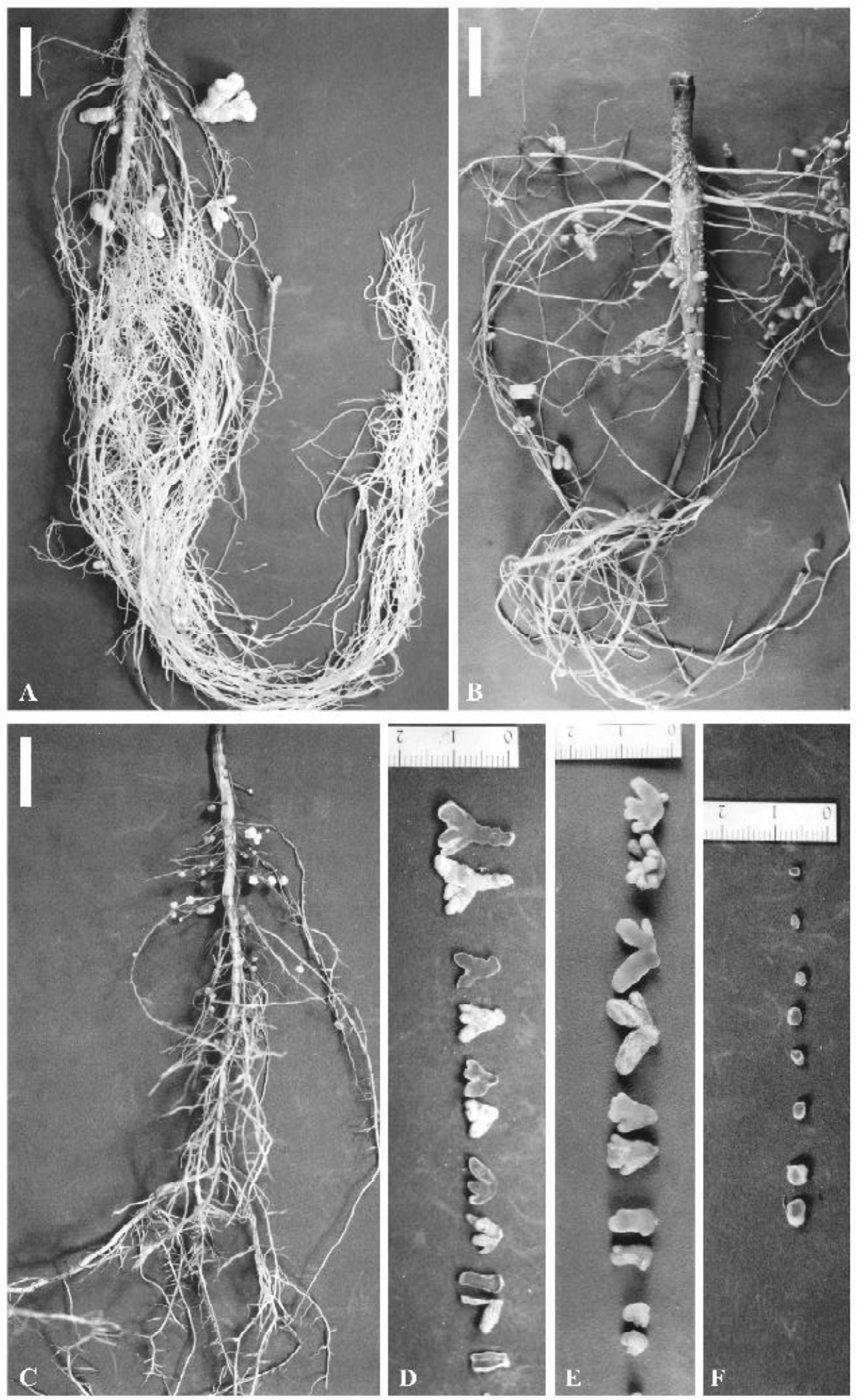

Figures 2A-C. Nodulated roots at 120 days. A. Enterolobium contortisiliquum (Vell. Conc.) Morong (bar $=2 \mathrm{~cm}$ ). B. Lonchocarpus muehlbergianus Hassl ( $\mathrm{bar}=2 \mathrm{~cm})$. C. Inga laurina $(\mathrm{Sw}$.) Willd. $(\mathrm{bar}=2 \mathrm{~cm})$. D-F. Excised nodules evidencing internal reddish hue due to leghemoglobin content. D. E. contortisiliquum. E. L. muehlbergianus. F. I. laurina. 
P-fertilizer treatment when dependent on biological nitrogen fixation by rhizobia (no $\mathrm{N}$ added), since $\mathrm{N}$ content in shoot tissue was high.

As demonstrated by Siqueira et al. (1998) in a study comprising 28 native species in woodland fragments in the state of Minas Gerais, Brazil, the response to treatments of $\mathrm{P}$ fertilization and mycorrhiza inoculation diminish with advance in succession. This agrees with our results, where $I$. laurina and P. elegans, late secondary or climax species (SMA,
2001), were less responsive to the $P$ treatments than the pioneer trees E. contortisiliquum and L. muehlbergianus. In addition, under nutrient stress conditions mycorrhizal effect on initial seedlings growth is greater in small seeded species (Siqueira et al. 1998). Seeds of E. contortisiliquum and L. muehlbergianus are smaller (3.600 and 1.160 seeds $\mathrm{kg}^{-1}$, respectively, according to Lorenzi, 1992) than I. laurina and P. elegans seeds (530 and 770 seeds $\mathrm{kg}^{-1}$, respectively, according to Lorenzi 1992; 1994).
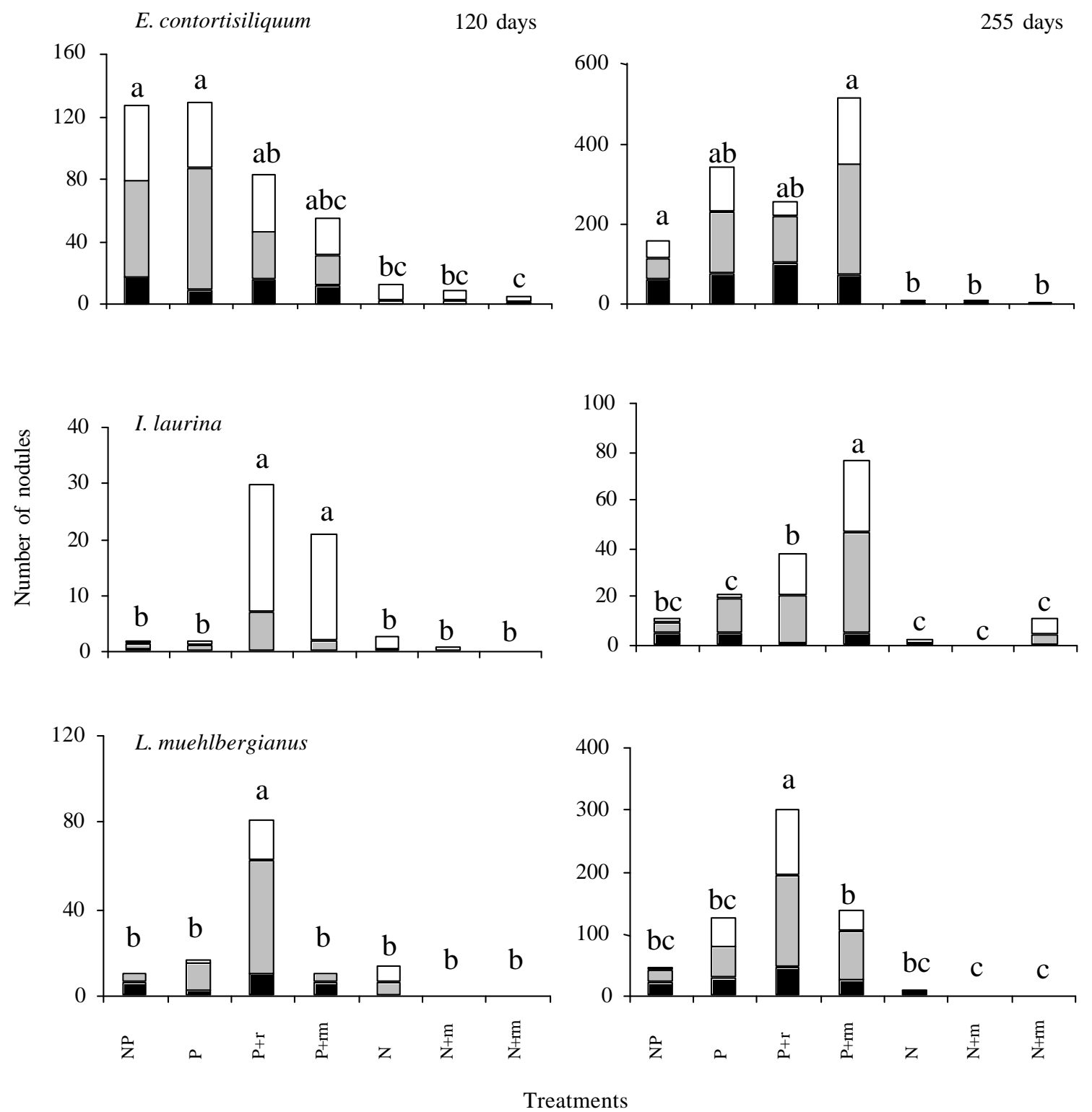

Figure 3. Average number of nodules per diameter size class (larger than $4 \mathrm{~mm}$, between 2 and $4 \mathrm{~mm}$ and smaller than $2 \mathrm{~mm}$ ) of Enterolobium contortisiliquum (Vell. Conc.) Morong, Inga laurina (Sw.) Willd. and Lonchocarpus muehlbergianus Hassl seedlings in response to treatments of mineral fertilization (NP, P, N) and inoculation with rhizobia (r), mycorrhiza (m) or both (rm) at 120 and 255 days of sowing. Total number of nodules followed by the same letter is not significantly different by ANOVA, followed by Duncan's test at $P<0.05 . \square=<2 ; \square=2$ a $4 ; \boldsymbol{\square}>4$. 
534 Patreze \& Cordeiro: Nodulation, arbuscular mycorrhizal colonization and growth of some legumes native from Brazil

Table 2. Nodulation parameters of Enterolobium contortisiliquum (Vell. Conc.) Morong, Inga laurina (Sw.) Willd, Lonchocarpus muehlbergianus Hassl and Platypodium elegans Vogel seedlings in response to treatments of mineral fertilization (NP, P, N) and inoculation with rhizobia (r), mycorrhiza (m) or both (rm) at 255 days. Legend: (nd) - not determined.

\begin{tabular}{|c|c|c|c|c|c|c|}
\hline \multirow[t]{2}{*}{ Treatments } & \multicolumn{4}{|c|}{ Nodule dry weight $(\mathrm{g})^{1}$} & \multirow{2}{*}{$\begin{array}{c}\text { ARA }^{2} \\
255 \text { days }\end{array}$} & \multirow{2}{*}{$\begin{array}{c}\operatorname{LegHb}^{3} \\
255 \text { days }\end{array}$} \\
\hline & $>4 \mathrm{~mm}$ & $2 \mathrm{a} 4 \mathrm{~mm}$ & $<2 \mathrm{~mm}$ & Total & & \\
\hline \multicolumn{7}{|c|}{ E. contortisiliquum } \\
\hline NP & $4.407 \mathrm{ab}$ & $0.811 \mathrm{ab}$ & $0.098 \mathrm{ab}$ & $5.317 \mathrm{a}$ & 77.61 & 0.396 \\
\hline $\mathrm{P}$ & $2.207 \mathrm{bc}$ & $0.213 \mathrm{~b}$ & $0.018 \mathrm{~b}$ & $2.439 \mathrm{ab}$ & 108.71 & 0.431 \\
\hline $\mathrm{P}+\mathrm{r}$ & $6.807 \mathrm{a}$ & $0.730 \mathrm{ab}$ & $0.038 \mathrm{ab}$ & $7.577 \mathrm{a}$ & 223.03 & 0.392 \\
\hline $\mathrm{P}+\mathrm{rm}$ & $3.533 \mathrm{abc}$ & $1.562 \mathrm{a}$ & $0.215 \mathrm{a}$ & $5.311 \mathrm{ab}$ & 101.23 & 0.244 \\
\hline $\mathrm{N}$ & $0.011 \mathrm{c}$ & $0.007 \mathrm{~b}$ & 0 & $0.018 \mathrm{~b}$ & 1.98 & nd \\
\hline $\mathrm{N}+\mathrm{m}$ & $0.007 \mathrm{c}$ & $0.002 \mathrm{~b}$ & 0 & $0.010 \mathrm{~b}$ & 4.67 & nd \\
\hline $\mathrm{N}+\mathrm{rm}$ & $0.001 \mathrm{c}$ & $0.001 \mathrm{~b}$ & 0 & $0.003 \mathrm{~b}$ & 1.87 & nd \\
\hline \multicolumn{7}{|l|}{ I. laurina } \\
\hline NP & $0.102 \mathrm{~b}$ & $0.034 \mathrm{~b}$ & $0.001 \mathrm{~b}$ & $0.138 \mathrm{~b}$ & 12.88 & 0.264 \\
\hline $\mathrm{P}$ & $0.350 \quad \mathrm{a}$ & $0.021 \mathrm{~b}$ & 0 & $0.373 \mathrm{a}$ & 11.40 & 0.372 \\
\hline $\mathrm{P}+\mathrm{r}$ & $0.016 \mathrm{~b}$ & $0.052 \mathrm{~b}$ & $0.006 \mathrm{ab}$ & $0.075 \mathrm{~b}$ & 6.64 & 0.496 \\
\hline $\mathrm{P}+\mathrm{rm}$ & $0.085 \mathrm{~b}$ & $0.100 \mathrm{a}$ & $0.010 \mathrm{a}$ & $0.196 \mathrm{~b}$ & 8.04 & 0.227 \\
\hline $\mathrm{N}$ & 0 & $0.004 \mathrm{~b}$ & 0 & $0.005 \mathrm{~b}$ & 0 & nd \\
\hline $\mathrm{N}+\mathrm{m}$ & 0 & 0 & 0 & 0 & nd & nd \\
\hline $\mathrm{N}+\mathrm{rm}$ & $0.001 \quad b$ & $0.012 \mathrm{~b}$ & 0 & $0.015 \mathrm{~b}$ & 1.47 & nd \\
\hline \multicolumn{7}{|c|}{ L. muehlbergians } \\
\hline NP & $1.895 \mathrm{a}$ & $0.407 \mathrm{a}$ & $0.019 \mathrm{ab}$ & $2.321 \mathrm{a}$ & 278.13 & 0.319 \\
\hline $\mathrm{P}$ & $1.186 \mathrm{ab}$ & $0.070 \mathrm{a}$ & $0.001 \mathrm{~b}$ & $1.257 \mathrm{ab}$ & 142.07 & 0.232 \\
\hline $\mathrm{P}+\mathrm{r}$ & $1.376 \mathrm{ab}$ & 0.418 a & 0.066 a & $1.86 \mathrm{a}$ & 341.22 & 0.333 \\
\hline $\mathrm{P}+\mathrm{rm}$ & $0.697 \mathrm{ab}$ & $0.257 \mathrm{a}$ & $0.030 \mathrm{ab}$ & $0.984 \mathrm{ab}$ & 321.48 & 0.234 \\
\hline $\mathrm{N}$ & $0.01 \mathrm{~b}$ & $0.006 \mathrm{a}$ & 0 & $0.016 \mathrm{~b}$ & 9.33 & 0.273 \\
\hline $\mathrm{N}+\mathrm{m}$ & 0 & 0 & 0 & 0 & nd & nd \\
\hline $\mathrm{N}+\mathrm{rm}$ & 0 & 0 & 0 & 0 & nd & nd \\
\hline \multicolumn{7}{|l|}{ P.elegans } \\
\hline $\mathrm{NP}$ & 0 & 0 & 0 & 0 & nd & nd \\
\hline $\mathrm{P}$ & 0 & 0.00126 & 0 & 0.00126 & 29.92 & nd \\
\hline $\mathrm{P}+\mathrm{r}$ & 0 & 0.0001 & 0 & 0.00016 & nd & nd \\
\hline
\end{tabular}

${ }^{1}$ Values followed by the same letter(s) are not statistically different at $5 \%$ level determined by Duncan test; ${ }^{2} \mathrm{ARA}$ - Acetylene reduction activity in ìmol $\mathrm{C}_{2} \mathrm{H}_{4} \cdot \mathrm{plant}^{-1} \cdot \mathrm{h}^{-1} \cdot 10^{-2} ;{ }^{3} \mathrm{LegHb}$ - leghemoglobin content in $\mathrm{mg} \mathrm{Hb} \cdot \mathrm{g}^{-1}$ fresh nodule.

The increasing concentration of soluble phosphate in the soil normally decreases the percentage colonization of roots by AMF (Smith \& Read 1997). In our experiment, the mycorrhizal colonization was relatively low, but the highest values were found in the treatments with higher P level. Moreover, mycorrhizal fungi colonized the seedlings of almost all treatments. This confirms that AMF are an integral part of the root system of almost all plants in the tropics, not only under natural conditions, but also in cultivation. Bereau et al. (1997) recorded 68 and 30\% of endomycorrhizas in Inga sp. in two of 12 sites of the forest of French Guiana. Carneiro et al. (1998) characterized the occurrence of AMF of P. elegans in the greenhouse as an average of 20 to $49 \%$ of infected roots. Frioni et al. (1999) reported that E. contortisiliquum, I. uruguensis and L. nitidus had levels of colonization by AM fungi of 60, 47 and $69 \%$, respectively, in the field.

Due to the low AMF colonization in our experiment, we could not observe the effects of the increase of $P$ acquisition by plants associated with mycorrhizal fungi, as discussed by Colebatch et al. (2002). Treseder \& Allen (2002) proposed a model where fungi are more efficient scavengers for soil nutrients than plant roots. Nevertheless the time of observation could be extended for some years, once the species studied are perennial trees and 255 days could be short time to observe the AMF infection, colonization and efficiency in the root system.

In our experiment nodulation was high, except for $P$. elegans, where average numbers of nodules were 4.33 and 0.66 for $\mathrm{P}$ and $\mathrm{P}+\mathrm{r}$ treatment, respectively, at the second harvest (data not shown). According to 
observations of Moreira (1997), Inga species showed averages of 0.4 to 2.6 nodules per plant; with two to seven $\mathrm{mg}$ of dry weight and E. maximum plants had 51.6 nodules weighing $147 \mathrm{mg}$. In our experiment, I. laurina had about forty times more nodules (approximately 80 nodules per plant), weighing $195 \mathrm{mg}$ (dry) and E. contortisiliquum plants about ten times more nodules (mean 500 per plant), weighing 5.310 in the P+rm treatment, compared with Moreira (1997) datas. In addition, L. muelhbergianus showed on average 302 nodules per plant in the $\mathrm{P}+\mathrm{r}$ treatment at 255 days from sowing. Cordeiro et al. (1996) examining some developmental and structural aspects of nodules of this species, found a maximum value of 158 nodules per plant.

The $\mathrm{N}_{2}$ fixing capacity of E. contortisiliquum, I. laurina and L. muehlbergianus was confirmed by the ARA assay. Some values of ARA were reported in the literature for species belonging to the same genera: 2.800 (in $\mu$ mol ethylene. $\mathrm{g}^{-1}$ fresh nodule. $\mathrm{h}^{-1}$ ) for I. uraguensis Hook \& Arn. (Frioni et al. 1998) and $0.098,0.18,0.09,0.06,0.1$ and 0.016 (in $\mu$ mol ethylene nodule. $\mathrm{h}^{-1}$ ) for E. gummiferum (Mart.) Macb., E. mongollo Mart., I. capitata Desv., I. luschnathiana Benth., I. nuda Salzm. ex Benth., I. sessilis (Vell. Conc.) Martius, respectively (Faria et al. 1984). The units are different on each case: in $g$ of nodules and per nodule. It is difficult to compare these data firstly because they are from different species and secondly because ARA can be influenced by season, soil temperature drought and photoperiod (Moro et al. 1992). Furthermore, acetylene reduction assay can only indicate relative differences in nitrogenase activity; the assay does not measure total nitrogenase activity because the assay itself causes a decline. Nevertheless it can be useful in measuring relative differences in $\mathrm{N}_{2}$ fixation potential with low levels of technology (Vessey 1994), as used in our experiment to compare the fertilization and inoculation treatments or to compare species, as long as the nodules must have the same type of growth.

Although in our experiments nodulation in P. elegans was low, this species is known to fix nitrogen (Tab. 2). Goi et al. (1984) detected acetylene reduction activity of $9.2 \mu \mathrm{mol} \mathrm{C}_{2} \mathrm{H}_{4}$ per nodule. $\mathrm{h}^{-1}$ and Faria et al. (1984) obtained $180 \mu \mathrm{mol} \mathrm{C}_{2} \mathrm{H}_{4}$ per nodule. $\mathrm{h}^{-1}$ in seedlings inoculated by a mixture of 222 strains of rhizobia.

The low nodulation in P. elegans may be associated with lack of specificity between host plant and rhizobia, since the strains inoculated were isolated from L. muehlbergianus. It could also be related to $\mathrm{P}$ deficiency, which can limit nodulation indirectly by reducing legume growth, rather than by direct action on the infection process (Bordeleau \& Prévost 1994). Thus, the slow growth of $P$. elegans and the low values of AMF colonization and nodulation (number of nodules, ARA and leghemoglobin content) show that this species must be more studied in relation to mineral nutrition.

The extent of root colonization cannot be an indication of AMF's ability to enhance plant growth as observed by and according to Roldan-Fajardo (1994) and Marques et al. (2001). An effective mycorrhizal colonization may affect nodule weight, leghemoglobin content and nitrogen fixing activity. The growth and development of seedlings in the greenhouse conditions with the use of non-sterilized soil may require only rhizobial inoculation, as found here for E. contortisiliquum, P. elegans and L. muehlbergianus plants that can form mycorrhizas with soil fungi. However, better results might be obtained with the use of selected mycorrhizal fungi. Our results support the evaluation of the effects of dual inoculation of these legume tree species under field conditions, as a way of enhancing plant survival.

\section{Acknowledgements}

This study was supported by the Brazilian Conselho Nacional de Desenvolvimento Científico e Tecnológico (CNPq) and chemical analysis were supported by Fundação para o Desenvolvimento da UNESP (FUNDUNESP). We thank Siu Mui Tsai from CENA-USP, for assistance in nitrogenase analysis. We are also grateful to Janet I. Sprent who provided critical comments to this manuscript.

\section{References}

Allen, O.N. \& Allen, E.K. 1981. The Leguminosae: A source book of characteristics, uses and nodulation. Madison, The University of Wisconsin Press.

Barbedo, C.J. \& Cicero, S.M. 2000. Effects of initial quality, low temperature and ABA on the storage of seeds of Inga uruguensis, a tropical species with recalcitrant seeds. Seed Science Technology 28: 793-808.

Becana, M.; Gogorcena, Y.; Aparicio-Tejo, P.M. \& SánchezDíaz, M. 1986. Nitrogen fixation and leghemoglobin content during vegetative growth of alfafa. Journal of Plant Physiology 123: 117-125.

Bereau, M.; Gazel, M. \& Garbaye, J. 1997. Les symbioses mycorhiziennes des arbres de la forêt tropicale humide de Guyane Française. Canadian Journal of Botany 75: 711-716. 
Bernacci, L.C.; Goldenberg, R. \& Metzger, J.P. 1998. Estrutura florística de 15 fragmentos florestais ripários da Bacia do Jacaré- Pepira (SP). Naturalia 23: 23-54.

Bordeleau, L.M. \& Prévost, D. 1994. Nodulation and nitrogen fixation in extreme environments. Plant and Soil 161: 115-125.

Brandon, N.J.; Shelton, H.M. \& Peck, D.M. 1997. Factors affecting the early growth of Leucaena leucocephala 2 . Importance of arbuscular mycorrhizal fungi, grass competition and phosphorus application on yield and nodulation of leucaena in pots. Australian Journal of Experimental Agriculture 37: 35-43.

Brundrett, M.C. 2002. Coevolution of roots and mycorrhizas of land plants. New Phytologist 154: 275-304.

Burity, H.A.; Lyra, M.C.C.P.; Souza, E.S.; Mergulhão, A.C.E.S. \& Silva, M.L.R.B. 2000. Efetividade da inoculação com rizóbio e fungos micorrízicos arbusculares em mudas de sabiá submetidas a diferentes níveis de fósforo. Pesquisa agropecuária brasileira 35(4): 801-807.

Carneiro, M.A.C.; Siqueira, J.O.; Moreira, F.M.S.; Carvalho, D.; Botelho, S.A. \& Junior, O.J.S. 1998. Micorriza arbuscular em espécies arbóreas e arbustivas nativas de ocorrência no sudeste do Brasil. Cerne 4(1): 129-145.

Catharino, E.L.M. 1989. Florística de matas ciliares. Pp. 61-70. In: Anais do Simpósio Sobre Mata Ciliar. Campinas, Fundação Cargill.

Colebatch, G.; Trevaskis, B. \& Udvardi, M. 2002. Symbiotic nitrogen fixation research in the postgenomics era. New Phytologist 153: 37-42.

Corby, H.D.L. 1988. Types of rhizobial nodules and their distribution among the leguminosae. Kirkia 13(1): 53-123.

Cordeiro, L.; Sprent, J.I. \& Mcinroy, S.G. 1996. Some developmental and structural aspects of nodules of Lonchocarpus muehlbergianus Hassl. Naturalia 21: 9-21.

De La Cruz, R.E.; Manalo, M.Q.; Aggangan, N.S. \& Tambalo, J.D. 1988. Growth of three legume trees inoculated with VA mycorrhizal fungi and Rhizobium. Plant and Soil 108: 111-115.

Eibl, B.; Fernandez, R.A.; Kozarik, J.C.; Lupi, A.; Montagnini, F. \& Nozzi, D. 2000. Agroforestry systems with Ilex paraguariensis (American holly or yerba mate) and native timber trees on small farms in Misiones, Argentina. Agroforestry Systems 48: 1-8.

Faria, S.M.; Franco, A.A.; Jesus, R.M.; Menandro, M.S.; Baitello, J.B.; Mucci, E.S.F.; Döbereiner, J. \& Sprent, J.I. 1984. New nodulating legume trees from South-East Brazil. New Phytologist 98: 317-328.

Faria, S.M.; Lima, H.C.; Franco, A.A.; Mucci, E.S.F. \& Sprent, J.I. 1987. Nodulation of legume trees from South East Brazil. Plant and Soil 99: 347-356.

Faria, S.M.; Siqueira, J.O.; Valee, F.R. \& Curi, N. 1995. Crescimento de leguminosas arbóreas em resposta a fósforo, nitrogênio, fungo micorrízico e rizóbio. I. Albizzia lebbeck (L.) Benth. Revista Árvore 19(3): 293-307.

Frioni, L.; Dodera, R.; Malatés, D. \& Irigoyen, I. 1998. An assessment of nitrogen fixation capability of leguminous trees in Uruguay. Applied Soil Ecology 7: 271-279.
Frioni, L.; Minasian, H. \& Volfovicz, R. 1999. Arbuscular mycorrhizae and ectomycorrhizae in native tree legumes in Uruguay. Forest Ecology and Management 115: 41-47.

Giovannetti, M. \& Mosse, B. 1980. An evaluation of techniques for measuring vesicular arbuscular mycorrhizal infection in roots. New Phytologist 84: 489-500.

Goi, S.R.; Faria, S.M. \& Neves, M.C.P. 1984. Fixação de nitrogênio, tipo de nódulo e ocorrência de ureídeos em leguminosas florestais. Pesquisa agropecuária brasileira 19: 185-190.

Gross, E.; Cordeiro, L. \& Caetano, F.H. 2004. Nodulação e micorrização em Anadenanthera peregrina var. falcata em solo de cerrado autoclavado e não autoclavado. Revista Brasileira de Ciência do Solo 28(1): 95-101.

Halliday, J. \& Nakao, P.L. 1982. The symbiotic affinities of woody species under consideration as nitrogen-fixing trees NifTAL Resource Document. Hawaii, University of Hawaii.

Hardy, R.W.F.; Holsten, R.D.; Jackson, E.K. \& Burns, R.C. 1968. The acetylene-ethylene assay for $\mathrm{N}_{2}$ fixation: laboratory and field evaluation. Plant Physiology 43: 1185-1207.

Khan, S.N. \& Uniyal, K. 1999. Growth response of two forest tree species to VAM and Rhizobium inoculations. Indian Forester 125(11): 1125-1128.

Lorenzi, H. 1992. Árvores Brasileiras- Manual de identificação e cultivo de plantas arbóreas nativas do Brasil. v.1, Nova Odessa, Editora Plantarum.

Lorenzi, H. 1994. Árvores Brasileiras- Manual de identificação e cultivo de plantas arbóreas nativas do Brasil. v.2, Nova Odessa, Editora Plantarum.

Marques, M.S.; Pagano, M. \& Scotti, M.R.M.M.L. 2001. Dual inoculation of a woody legume (Centrolobium tomentosum) with rhizobia and mycorrhizal fungi in south-eastern Brazil. Agroforestry Systems 52: 107-117.

Montagnini, F.; Eibl, B.; Grance, L.; Maiocco, D. \& Nozzi, D. 1997. Enrichment planting in overexploited subtropical forests of the Paranaense region of Misiones, Argentina. Forest Ecology and Management 99: 237-246.

Moreira, F.M.S. 1997. Nodulação e crescimento de 49 leguminosas arbóreas nativas da Amazônia em viveiro. Revista Brasileira de Ciência do Solo 21: 581-590.

Moro, M.J.; Domingo, F. \& Castro, F.B. 1992. Acetylene Reduction Activity (ARA) by the shrub legume Adenocarpus decorticans Boiss. in Southern Spain (Almería). Acta Ecologica 13(3): 325-333.

Mosse, B. 1975. Specificity in VA mycorrhizas. Pp. 469-484. In: F.E. Sanders; B. Mosse \& P.B. Tinker (eds.). Endomycorrhizas. London, Academic Press.

Munro, R.C.; Wilson, J.; Jefwa, J. \& Mbuthia, K.W. 1999. A low-cost method of mycorrhizal inoculation improves growth of Acacia tortilis seedlings in the nursery. Forest Ecology and Management 113: 51-56.

Nilsson, T.T. 1989. Levantamento do potencial econômico da mata ciliar e sugestões quanto ao seu aproveitamento racional. Pp. 112-155. In: Anais do Simpósio sobre Mata Ciliar. Campinas, Fundação Cargill. 
Philips, J.M. \& Hayman, D.S. 1970. Improved procedures for clearing roots and staining parasitic and vesiculararbuscular mycorrhizal fungi for rapid assesment of infection. Transactions of the British Mycologycal Society 55(1): 158-161.

Rodrigues, R.R. \& Nave, A.G. 2000. Heterogeneidade florística das matas ciliares. Pp. 45-72. In: R.R. Rodrigues \& H.F. Leitão Filho (eds.). Matas Ciliares: conservação e recuperação. São Paulo, Editora da Universidade de São Paulo.

Roldan-Fajardo, B.E. 1994. Effect of indigenous arbuscular mycorrhizal endophytes on the development of six wild plants colonizing a semi-arid area in south-east Spain. New Phytologist 127: 115-121.

Romagnolo, M.B. \& Souza, M.C. 2000. Análise florística e estrutural de florestas ripárias do Alto Rio Paraná, Taquaruçu, MS. Acta Botanica Brasilica 14(2): 127-242.

Santiago, G.M.; Garcia, Q. \& Scotti, M.R. 2002. Effect of post-planting inoculation with Bradyrhizobium sp. and mycorrhizal fungi on the growth of Brazilian rosewood, Dalbergia nigra Allem. ex Benth., in two tropical soils. New Forests 24: 15-25.

Silva, S.M.; Silva, F.C.; Vieira, A.O.S.; Nakajima, J.N.; Pimenta, J.A. \& Colli, S. 1992. Composição florística e fitossociologia do componente arbóreo das florestas ciliares da Bacia do Rio Tibagi, Paraná: 2. Várzea do Rio Bitumirim, município de Ipiranga, PR. Revista do Instituto Florestal 4: 192-198.
Siqueira, J.O.; Carneiro, M.A.C.; Curi, N.; Rosado, S.C.S. \& Davide, A.C. 1998. Mycorrhizal colonization and mycotrophic growth of native woody species as related to successional groups in Southeastern Brazil. Forest Ecology and Management 107: 241-252.

Smith, S.E. \& Read, D.J. 1997. Mycorrhizal symbiosis . London, Academic Press.

Sprent, J.I. 2001 Nodulation in Legumes. Kew, Royal Botanic Gardens.

Tilki, F. \& Fisher, R.F. 1998. Tropical leguminous species for acid soils: studies on plant form and growth in Costa Rica. Forest Ecology and Management 108: 175-192.

Trannin, I.C.B.; Moreira, F.M.S. \& Siqueira, J.O. 2001. Crescimento e nodulação de Acacia mangium, Enterolobium contortisiliqqum e Sesbania virgata em solo contaminado com metais pesados. Revista Brasileira de Ciência do Solo 25: 43-753.

Treseder, K.K. \& Allen, M.F. 2002. Direct nitrogen and phosphorus limitation of arbuscular mycorrhizal fungi: a model and field test. New Phytologist 155: 507-515.

Vadez, V.; Beck, D.P.; Lasso, J.H. \& Drevon, J.J. 1997. Utilization of the acetylene reduction assay to screen for tolerance of symbiotic $\mathrm{N}_{2}$ fixation to limiting $\mathrm{P}$ nutrition in commom bean. Physiologia Plantarum 99: 227-232.

Vessey, J.K. 1994. Measurement of nitrogenase activity in legume root nodules: In defense of the acetylene reduction assay. Plant and Soil 158: 151-162. 